\title{
Inter-mixing Indiannesss with Thainesss in selected Thai Novels
}

\author{
Sophana Srichampa \\ Centre for Bharat Studies \\ Research Institute for Languages and Cultures of Asia \\ Mahidol University, Thailand
}

\begin{abstract}
This article studies the Indian settings and plots of eight Thai novels by seven writers based on the period of the works and the relative experience of the writer. The results are as follows: During the early Ratanakosin period, only one piece of Thai poetry recording the lives of two Hindu Indians fighting over a Melayu woman was written using a Thai setting. In the Middle Ratanakosin period, one renowned book about India recounted the visit of a young King Rama V of Siam to India to experience and learn from the positive and negative experience of colonized countries. His Majesty was inspired by that visit and reformed Siam (former name of Thailand) into a dynastic state with numerous new economic political and social developments. In the current Ratanakosin period of rampant globalization, "Indianness" presented in the settings and protagonists are plotted in many Thai novels mixing with "Thainess" through Thai or Indian-Thai characterisation and aspects of culture and concepts related to Hinduism and Buddhism. "Dharma" and "Karma" are the main key reflections found in Thai works. It can be concluded that, through their art, Thai novelists serve de facto roles as cultural ambassadors linking Thai readers to India.
\end{abstract}

Keywords: Buddhism, Hinduism, India, novel, Thailand

Cites as: Srichampa, S. (2019). Inter-mixing Indiannesss with Thainesss in selected Thai Novels. Arab World English Journal for Translation \& Literary Studies, 3 (2). 152-164.

DOI: http://dx.doi.org/10.24093/awejtls/vol3no2.13 
AWEJ for Translation \& Literary Studies Volume, 3 Number 2. May 2019

Inter-mixing Indiannesss with Thainesss in selected Thai Novels

Srichampa

\section{Introduction}

Thailand, as a part of Suvarnabhumi, has had a long relationship with India-thousands of years in fact, with trade being the main objective of Indians sailing from India to Southeast Asia. Hinduism, introduced by brahmins who accompanied Indian traders, was accepted and adapted by rulers in the region. In the $3^{\text {rd }}$ century BCE, Buddhism was spread by Sona and Uttara in Nakhon Pathom province. Buddhism and Hinduism mixed with local administrative systems and beliefs to become the raja system. Venerable Buddhadasa, the most famous Thai monk and social reformer, once stated that Hinduism, Buddhism, the four basic human needs, and the language and culture of India all influenced Siam to become the Thai society we know today. There is a combination of Indian flesh and blood in ours. We unconsciously have Hinduism as our mother and Buddhism as our father'. Buddhadasa asked Thai people to express their gratitude to India. (Buddhadasa, 1980, p. 18, 24).

During the time of colonization under the British up to the post-colonization era, waves of Indians from Punjab, including today's Pakistan and other areas, migrated to Siam as it was the only country in Southeast Asia not colonized by Europeans. They sought to make their living there, often by selling clothes in Bangkok's Pahurat area or by walking door to door sometimes as far as neighboring provinces. Earlier arrivees helped the newcomers and once able to stand on their own feet, they would venture off to make their own way in life. Clothes and textiles are part of Indian identity in Pahurat despite many of the later generations of Indians in Thailand choosing not to take up the business given the new career opportunities afforded them by their higher education, which the first and second generations never had. Most have forgone the textile trade in favour of technology and other commercial pursuits. The new generation is Thai but they look Indian and although not many Indians cross-marry with Thais, they mix with them in their daily life through work, study, religious and social activities.

The early generation of Indians in Thailand, without the benefit of a good education, was a forced to sell goods such as cloth and mosquito nets door to door, usually financed by loans from money-lenders who charged high daily interest. Thus the Thai saying "Meet an Indian and meet a snake, beat the Indian first" (Kaew-Uraj, 2011.). This depicts the long held negative reputation of Indians, that remains deeply imbedded in the Thai mindset to this day.

Nonetheless, the Indian government opted to apply cultural diplomacy to develop a positive profile by focusing on arts, languages and culture and offering annual scholarships for various education programs to students in many countries. As a result, over 50 years, more than a thousand Thai students have graduated from India by virtue of various Indian scholarship schemes. Today many Thais study there of the own accord or at the numerous Thai universities that teach about India as part of eastern civilization, history, literature, religion, languages and culture studies. In 2009, the Indian Cultural Center was established in Bangkok, which functions as a hub of Indian 
arts, languages and culture promotion and exchange between India and Thailand. Its aim is to bring the peoples of both countries closer for better understanding. Also, many Thai Buddhists choose to go on pilgrimages to sacred Buddhist sites in India or visit renowned tourist places such as Taj Mahal, Kashmir, Chennai, Mumbai, New Delhi and Kolkata. Air connectivity between India and Thailand is very convenient nowadays with direct flights every day that facilitate travel and opportunities to learn about and know each other. With their knowledge, experiences and perceptions of India, many Thai writers use Indian setting and protagonists inter-mixing in their Thai novels.

\section{Objective}

The objective of this paper is to discover the Indian settings and genres presented in selected Thai novels.

\section{Methodology:}

Seven writers and eight works were selected for analysis: one literary work, one historical documentary, and six novels were reviewed which varied according to the period in which they were written and the seniority of the writers.

\section{Results and findings:}

The selected works are presented according to the periods as follows:

\section{Early Ratanakosin Era}

The early Ratanakosin era included the reigns of Kings Rama' I to III. (C.E.1782- C.E.1851) (Terwiel, 1983). One outstanding novel that was composed in this period is "Radenlandaj" which is described below.

This first work of literature about India was written in the reign of King Rama III and comprised various styles of Thai poetry. The setting for Radenlandaj is Bangkok, Thailand. The poems describe the life of a Hindu Indian named "Landaj" who is a wonderer, does not speak Thai well, lives near the Devasthan (Brahmin temple) and earns his living as a beggar by singing and playing the fiddle. There is another Indian character known as "Khaek Pradu" who owns cows. His wife is "Pradae", a Melayu woman. One day both men have a fight over this woman. The story was already well known but Phra Maha Montri reinterpreted it as a play representing the first written work based on the true story of a Hindu Indian. In an amusing way, he used royal vocabularies to describe the life of an ordinary man like Landaj, a story described as "one of the most parodical stories which is hardly comparable" (Vitchayaprakorn, 2006, http://www.human.nu.ac.th/jhnu/ journal_detail.php?m=4\&a=50).

Radenlandaj reflects on the life of a beggar who earns his living playing music in exchange for offerings. Landaj represents the wonderer who appears at different times and in different 
contexts through history. The setting of the story is in the proximity of the Brahmin Swing near the Devasthan which is on the Ratanakosin Island in Bangkok and is a place where many the wonderers today pass their time (Nathi, 2010).

Radenlandaj was the first work of social satire in Thai and the first to record the existence of a beggar: "This is the story of a beggar. Before that, in the Sukhothai and Ayutthaya Kingdoms, there might have been burglars too, but there is no record" (Pitak, 2014, p. 2).

\section{The Middle Ratanakosin Era}

The middle Ratanakosin era covered the reigns of King Rama IV-King Rama VI (from C.E. 1851-C.E.1926) (Terwiel, 1983). One renowned book about India from that time is discussed below.

During the British colonial period, King Rama V, as the 19 year old young king of Siam (Today is Thailand), visited India in 1872. The purpose of his visit was to survey the situation there in terms of military, politics, and socio-cultural scenario to be used as possible models for Siam (Sahai, 2002). Kasetsiri (2016) opines that:

His visit during the early reign of the young king, especially to the British colonies of Singapore (1870), India (with Burma) in 1871, was extremely important to the "reform" and the royal policies of Siam during the reign of Kings Rama V, VI and VII (until Revolution 24 June 1932). Such reforms in the reign of King Rama V made Siam a "dynastic state" that centralized power with the king and became "absolutism" more than a "nationstate "(p.4).

There is a book written in 2002 about his visit entitled "India in 1872: As Seen by the Siamese" by the Indian scholar Professor Dr. Sahai Sachchidanand, which was translated into Thai by Kanthika Sri-udom in 2003. This book is a good reference to India under the British Raj from the viewpoint of the young Siamese king.

During the period of colonization in Asia, which impacted Siam less than its neighbours, the young Siamese king sought to learn how those colonized countries were affected, India in particular. He visited them to learn how best he could rule and keep Siam safe from being colonized itself. He sailed to the port of Calcatta, the then capital of British Raj, and stayed for 47 days. At that time, India had been under British rule for more than a hundred years and had had its infrastructure developed and modernized: railways, telecommunications, telegraph systems, roads and canals connected to the main rivers. Western education, a western-styled military, foundries, coins, docks, prisons, museums, zoos, religious places and palaces were all provided by the British. All this represented "westernness" or "modernity". At the same time, the young king experienced the abolition of the Maharaja system in the process, so he witnessed both positive and negative aspects of western colonization in India. Upon returning to Siam, he instigated development 
projects by applying "western" concepts and using "India as a role model for Siamese reform" (Muksri, 2003). The King together with leaders of the nobility, drove the modernization process quickly by introducing a taxation system, reengineering the political system and abandoning outdated traditions such as slavery and crawl. (Wongthet, 2016).

These two works provide a positive view of India from a Thai perspective. In "Radenlandaj", the presentation of the poor Hindu beggar reflects a Thai predisposition to have fun. "India in 1872: As Seen by the Siamese" on the other hand, is a valuable historical record compiled by the renowned Indian scholar and translated into Thai as an inter-cultural work for both sides to learn from.

\section{Current Ratanakosin Era}

In the reign of King Rama IX, there were numerous Thai novels written with foreign countries as settings. India was one such country that inspired Thai writers. The selected works studied in this part are presented according to the periods of publications and the seniority of the writers in Thai society.

A number of Thai writers have used elements of Indian history, geography, literature and knowledge in their plots and settings, and the first writer introduced here is Phnomthien. He wrote his first novel, "Chulatrikhun", in 1948 when he was in secondary school. It is a tragic romance novel. Chulatrikhun is the point where two rivers the Ganga and the Yamuna merge with the milky way from heaven to become three rivers. He describes the tragic romance as follows: Dararai-philat is a beautiful princess from Varanasi who prays at Chulatrikhun to become an ugly woman because she does not want her life to end like that of her beautiful mother. She meets Ariyawat, the king of Magadha who falls in love with her at first sight. Their destiny is complicated and tragic when, in the end, Ariyawat betrays her by marrying another princess, leading Dararai-philat to take her own life at Chulatrikhun.

This retro fantasy is one of the most popular novels in Thailand and has been reproduced as a radio drama, film and stage drama at various times. Moreover, five songs related to the story were composed.

By the same writer, with another Indian setting is "Sivaaraatri". Sivaaraatri means "A night of sin floating; it is Siva night". This is a beautiful novel by Phnomthien and written in a style that cannot be copied. (Kananurak, 2001). Four volumes have been published at various times. The plot revolves around a battle between Aryan and Milakha (Dravidian), but is sprinkled with romantic elements. In the story, the Aryans, led by Phitsanu Maharaja, invade the lands of the Dravidians. They want to kill all new born Dravidian babies because a prophesy foretells that on Sivaaraatri, 
Dravidian babies will defend their ancestral lands and defeat the Aryans. Three babies are born to the Dravidian King on Sivaaraatri and protected by various groups: one baby is cared for by a bandit; the second baby by a magician and the third baby by a priest. They do not know each other, only that the babies have the same royal seal on their backs. Twenty years later, now men, the three join together to fight for their freedom. The war causes losses on both sides, but finally the Dravidians prevail and soon realize what a disaster war brings. As a result, they succeed in uniting all groups and declare that, no matter who, they are one Jambudvipa people.

Phnomthien, who is a renowned writer of Bharat novels, explained the background to this novel saying: "I wrote this novel after studying the theology and indology of India and literature written by King Rama VI which inspired me... It was the history of India when Aryan invaded Jambudvipa where Dravidian resided around 1,500 B.C.E. establishing the myths that eventually produced the Hindu gods". (Soythong and Tulaphitak, 1999, p. 4).

The following are examples of two Thai readers' impression of this novel.

(1) "Whoever reads Sivaaratri three times need not worry about how to use Thai anymore". (Pantip, 2015, https:/pantip. com/topic/34053932).

(2) "It's very long, more than two thousand pages. But it is fun and captivates readers with good advice".

(Jidapa, 2014, https://pantip. com/topic/34053932.)

The second renowned writer is Thommayanti. She wrote "Sivalaj" which has two settings. One setting is in India during the time of King Ashoka, and the other is Thailand. The main characters are Thais of Indian extraction. The genre is mystery. Wamarin, the female protagonist, is an IndianThai model, who her Thai diplomat family adores. She often experiences strange premonitions which are familiar to her but she does not know why or where. When she is contacted for a fashion shooting in India, she accepts the job and decides to explore the area around Rishi Gate, the origin of the river Ganges. She gets lost but meets her Thai mother. The photography production team includes Ruthara, who is working as a coordinator shooting at the Taj Mahal. Along the way, Wamarin comes face to face with her karma and Ruthara tells her that he was the mouth of Mahadeva (Siva). They go to 'Sivalaj' together to change her bad karma, which she is constantly trying to avoid. This story mixes Buddhist and Hindu elements as well as the reincarnation of the male and female protagonists.

Examples of the reflections of some readers of this novel include:

(3) "I like this novel very much because of the beautiful language. The story appeals to me."

(Monaliz, 2014, https://Www.goodreads.com/book/show/22014794 ) 
AWEJ for Translation \& Literary Studies Volume, 3 Number 2. May 2019

Inter-mixing Indiannesss with Thainesss in selected Thai Novels

Srichampa

(4) "I get so overcome with emotion that I cry after reading some of the poems (in this novel). I am a fan of Thommyanti".

(Tam, n.d., https://writer.dek-d.com/writer/story/viewlongc.php?id=117900\&chapter=5.)

The third well-known writer is Sophak Suwan. She was the first writer to introduce to readers the nature of different races, religions, politics and cultures in the foreign lands. Although these issues are not insignificant, equality of human beings is more important (Satjaphan, 2013). Two of her novels involve Indian settings. The first one is "Meet Each Other under the Stars" which is set in the British colonial period and is an adventure romance story. The male protagonist, Khich-han Salim Agbar, is a descendant of the Mughal King Agbar. The female protagonist is Iris, the daughter of Doctor Schneider, a German doctor, and his English wife. Iris spends her childhood with her English aunt and an Indian uncle who is the private doctor to Khich-han's mother, a princess. Khich-han is sent to study in England with Heirich, Iris's' brother, at the same time that Iris has to move back to stay with her family in Austria. Doctor Schneider loves to climb mountains. His dream is to climb in the Himalayas, and luckily one day he and his team are sent to survey there. But the mission has not yet finished when World War II breaks out and they are arrested and ultimately disappear. After the war, Iris and her brother go to India. Together with Khich-han, they search for their father as far as Tibet with the help of Junk Yimpa, a Tibetan man who is a friend of Khich-han and Doctor Schneider's family. Finally, they find Doctor Schneider and they all decide to help Junk Yimpa find work in Lasa. Unfortunately, the Chinese invade Tibet and they all have to flee back to India. Iris becomes a volunteer teacher in Dhammasala, and in the end, Khichhan, who becomes an Indian diplomat, marries Iris and all live happily ever after.

One reader of this novel commented as follows:

(5) "Reading about the 50th anniversary of the Tibetan occupation made me think of this Sophak Suwan novel, which is one that I like very much. The story begins about a decade before the Second World War. It starts in India and concludes in Tibet. The writer added a lot of information, but it's still readable.

The male protagonist, Kich-han, speaks very little and there are only two romantic scenes in the story between Kich-han and Iris, but Sophak Suwan was able to make us feel the romance and love between the two".

(Pichayaratana, 2009, https://www.bloggang.com/mainblog.php?id=pichayaratana\& month $=01-042009 \&$ group $=1 \&$ gblog=1)

The second novel by Sophak Suwan about India is "Justmina-Mahal". The setting is in India which is full of geographic and cultural diversity. The genre is romance. Malatee Mala is an Indian princess engaged to a prince since she was 5 years old by her Indian grandmother. After her Indian 
father and Thai mother, the King and Queen, die in an accident when Malatee is 8 years old, she and her nanny go to stay with her Thai grandparents in Thailand. As a teenager, she goes to England to study nursing and returns to India to work in public health with an NGO. There she meets her financé, Ronnachit Jirendra Gandawhar and Major General Isara Jairaj Gandawhar who is his step brother. In a happy ending, she marries her step brother who is Maharaja of Arunapura and becomes Maharani.

Reviews of this story include likes and dislikes:

(6) "This novel is fun but it's difficult to read; too much of description, letter writing to each other and a lot of English vocabularies..."

(7) "This novel also mentions the Thai family. I like the impressive advice of the grandfather to his granddaughters".

(Javee, 2017, https://Www.bloggang.com/mainblog.php?id=javee\&month=26-12-

$2010 \&$ group $=8 \&$ gblog $=11$ )

(8) "I've already read it. It's lovely. The male character is very tender as is the female one since she is so young...I like it".

(Laylin, 2017, https://www.bloggang.com/mainblogphp?id=javee\&month=26-122010\&group $=8 \&$ gblog $=11$ )

Warangkhana is the pen name of the Thai writerwho wrote "Sari", a Thai novel set in both Thailand and India. The main character, Trat, is a Thai student who earns a scholarship to study science at Aligarh Muslim University in India. He is attracted to an Indian Muslim princess who is around ten years older than him, but he also loves the princess' niece, Praveen, who is studying at the same university. The princess is a kind-hearted woman who is well regarded and respected by others because of her charity. Trat is offered private English classes with the princess as he is almost retired. He eventually agrees to become her husband and moves to live with her in the palace. Although he feels as if he has sold himself out for success, he believes he had no choice as he does not want to go back to Thailand as a failure, so he serves her as she demands. However, he soon attracts the attention of another niece, Muni, who has fallen in love with him. He does not really love her but an affair together leaves Muni pregnant. The princess soon learns of this but decides to help Muni, who is stubborn and rejects the princess' advice. In the end, the princess arranges the marriage of her other niece, Praveen, whom Trat loves, as she feels guilty for stealing Trat from her. But Muni prevents the marriage out of jealousy by fatally shooting Praveen. Muni also dies, but her daughter, named "Little Praveen", is saved and taken care of by Trat who returns to Thailand after graduation. Trat finally gets married to his cousin, Amravadi, who looks after "Little Praveen" as her mother. This novel is a love triangle and tragedy. 
AWEJ for Translation \& Literary Studies Volume, 3 Number 2. May 2019

Inter-mixing Indiannesss with Thainesss in selected Thai Novels

Srichampa

The last writer is Chayaphim. Her novel is "Love Solok beneath Star Ray". The setting is in India. The male protagonist, Ram Anderson, is an English-Indian, and the female is Laksmi who is Thai. The story is a romance. Broken hearted, Laksmi departs Thailand for India with the idea to write a new novel. She meets Ram who is a guide and henna artist. Feelings for each other gradually form into a deep relationship but there are many obstacles that test their love. But as this is real love, like that between the goddess Laksmi and the god Ram, it has a happy ending.

The following are comments by readers:

(9) "The story is about Indian people and tradition. It's hard to find novels like this in my opinion. I've never read other such novels. The writer depicts the beauty of this country which we never thought of visiting before. But after reading this novel, I am inspired to go there. I have learned about the customs and gained other knowledge...”.

(Lookpla, 2013, https://Www. goodreads.com/book/show/13371427)

(10) "This novel covers various genres. The first part is romantic, and at the same time, it documents the arts and culture of India. The last part is romance mixed with drama..."

(May, 2017, https://Www. goodreads.com/book/show/13371427)

\section{Discussion}

During the Ratanakosin dynasty, there was significant Indian migration to Siam. Indianness is the theme of the Thai literary work, "Radenlandaj", which is based on a real story recounted in a humorous style using high language. It is an outstanding piece of literature and is included in the curriculum for secondary school students. In general, Thai people do not discriminate against "otherness" by using vulgar words, and this work exemplifies the keen potential of the writer as teacher. Moreover, the story underlines two facts: 1) wonderers like Landaj have been a part of Thai society since the beginning of the Ratanakosin era; 2) Thailand has always been a multicultural society.

The historical documentary "India in 1872: As Seen by the Siamese" by Indian scholar Professor Dr. Sahai Sachchidanand follows King Rama V's 92 days of travel throughout India, recording the history and events of the time in detail never before available to Thai readers. The writer, as an Indian who knew and understood Indian culture well, included items from the mass media written by both westerners and Indians in English and Hindi to supplement his descriptions. It shows how truly important India has been to Thailand (Sri-Udom, 2018) and offers a view of India as a reflection of the British raj, with both positive and negative consequences. As an outsider from a small independent country, the then young King of Siam learned many new things from the experience, demonstrating that no matter how seemingly different, Siam (Thailand) could and can learn much from India as the links between the two are so long and strong.

Arab World English Journal for Translation \& Literary Studies 
The selected Thai novels from the current Ratanakosin period reviewed in this study represent modernization through which the writers express both ."Thainess." and ."Indianness". India and Indianness has been an inspiration for many Thai writers throughout their lives and has enriched the knowledge and experiences through study, travel and musings that are ultimately expressed in their stories. Aiewsriwong (2017) said, regarding the foreign settings in Thai novelism, "Even though the novel used foreign scenes and foreign protagonists throughout the story, foreign lands are not important except it is exotic background, like spices we never taste...". But if we consider readers'comments, it is clear that when writers of these genres of fiction insert South Asian elements through characterization and settings, readers are able to taste the essence of India and learn from it. Aiewsriwong also insists that the writers should pay attention to the 'otherness' that reveals the diverse ways of thinking, ways of life and beliefs of foreign lands, as depicted in the settings and exposed by the characters, without resorting to full blown representations and explanations. Nevertheless, some writers are unable to do this well so readers responded quite negatively to the overdetailed descriptions of the Indian scenes in the stories.

'Thainess' is expressed through the Thai or Indian-Thai characters' behavior as well as aspects of culture and concepts which are a blend of Hinduism and Buddhism. A feature of most Thai novels is the principle of karmic reward and retribution-Do good things and good things will be done to you. Do bad things and bad things will be done to you'. Phnomthien, for example, states that

Humanity is the first instinct of humans. Humanity will cause conscience, ethics and morals to follow later... I think "Dharma" is the most important thing in human life and I try to reflect it in all of my literary works in order to lend this conscience to readers indirectly.

(Sophapong, n.d.)

At the same time, ."Indianness." is represented through the Indian characters and setting, which convey the history, geography, religion, beliefs, language and culture of the time. The writers combine their knowledge of India with their creative imaginings and experiences of India and blend them into the stories. Therefore, not only are these novels sources of entertainment, but the mix of "Indianness" and "Thainess" offers insight and knowledge for readers through the beautiful prose and mesmerizing use of language. Some novels are admired by the readers and fans of respected older writers such as Phnomthien, Thomayanti and Sophak Suwan. But there are also some readers who may not appreciate certain over-stylised descriptions in the stories, as stated in some comments by readers. A number of these novels have been republished many times and produced in other entertainment forms such as films, dramas, TV series and songs, which serve to promote India to Thais through popular culture. New writers inspired by these stories, increasingly 
choose India as a travel destination for real experiences and inspiration for modern Thai novels, often with Indian settings.

The image of India in Thai society is one of a civilized country that has strongly influenced Thai religion and culture throughout history. Many Thai novels prefer to present "Indianness". based on historical, spiritual and cultural sources in attractive literary styles. In so doing, "Thainess" is portrayed through the Thai characters in a glamorized setting. The works of Thai novelists can thereby serve as cultural ambassadors linking Thai readers to India, encouraging readers to survey more about India for themselves after turning the final page. By the same token, if Thailand is used as their setting, reciprocal promotion will open readers from both countries to the delights and wonders of each other's societies, history and peoples.

\title{
Conclusion
}

In the early Ratanakosin era (C.E1782-C.E.1851), Indianness was reflected through descriptions of real life two Hindu Indians and one Melayu woman. The setting was Thailand. In the current period of globalization, although many Thais still have negative attitudes towards Indians, many Thai writers are inspired to mix both Thai and Indian elements into settings and protagonists in their novels without feeling "otherness". According to the data, five types of settings were identified 1) Thai setting with Indian males and foreign female protagonist, 2) Indian setting with Indian male and female protagonists, 3) Indian and Thai settings with local Indians, 4) Indian and Thai settings with Indian and Thai male and female protagonists, and 5) Indian setting with Thai protagonists. In terms of genres, an Indian perspective and flavor is also added to the content of some Thai novelsmostly mystery, adventure and tragedy mixed with romance. Thai novels reflect "Indianness" and "Thainess" through karmic reward and retribution which are based on Buddhism and Hinduism. These selected novels not only entertain Thai readers, but also encourage Thai readers to feel closer to India.

\begin{abstract}
About the Author
Dr. Sophana Srichampa is an Associate Professor in Linguistics at the Research Institute for Language and Cultures of Asia, Mahidol University, Thailand. One of her research interests is the relation between India and Thailand in terms of socio-cultural perspectives. She is the author of several articles related to language, culture and society. ID ORCID is https://orcid.org/0000-00033936-4963.
\end{abstract}

\section{References}

Aiewsriwong, N. (2017). Phai-rat-ni-jaaj-thai (Thai novels with foreign setting). Available at https://www.matichonweekly.com/column/article_40553.

Buddhadasa, B. (1980). Gratitude of India to Thai. Bangkok: Mae Kham Phang. 
AWEJ for Translation \& Literary Studies Volume, 3 Number 2. May 2019

Inter-mixing Indiannesss with Thainesss in selected Thai Novels

Srichampa

Chayaphim, (2011). Salok-rak-taaj-saeng-daaw (Love Solok beneath the Star Ray). Bangkok: Phimkham.

Celeb Online. (2015). Pleasant day with Phanomthien, Chatchai Wisetsuvarnabhumi. Available at http://www.manager.co.th/CelebOnline/ViewNews.aspx?NewsID=9570000043824

Javee (penname). (2017). Justmina-Mahal. Available at https:/www.bloggang.com/mainblog. php?id=javee \&month=26-12-2010\& group=8\&gblog=11.

Jidapa, M. (2017). Shiwaratri Vol. I. Available at https://www.goodreads.com/book/show/207461811.

Kaew-Uraj, R. (2011). What to beat between khaek and snake? Available at https:/www.gotoknow. org/posts/467412

Kananurak, M. (2001). The Important people of Pattani. Available at http:/www. kananurak.com/mcontents/marticle.php?headtitle=mcontents\&id=74142

Kasetsiri, C. 2016. King Rama $V$ and his visit India in 1871and understanding of the reform of the reign. Bangkok: Dream Catcher Graphic Co.Ltd. Available at http:/54408 activeboard. com/t2619429/5/.

Kledthai Publishing House. (2017). A complete version of Kamnita-Vasithi. Available at http://www.kledthai. com/9789747033977.html.

Laylin, (penname) (2017). Justmina-Mahal. Available at https://www.bloggang.com/ mainblogphp?id=javee\&month=26-12-2010\&group=8\&gblog=11.

Lookplam (penname). (2013). Love Solok beneath Star Ray. Available at https:/www.goodreads. com/book/show/13371427

May (penname). (2017). Love Solok beneath Star Ray. Available at https:/www.goodreads. com/book/ show/13371427.

MBookstore. (2013). Inaugurate three renowned novels, three styles of Warangkhana. Available at https://www.facebook.com/pg/Mbookstores/photos/?tab=album\&album_id=496330233798124

Monaliz, J. (2014). Sivalaj. Goodreads. Available at https://www.goodreads.com/bookshow/ 22014794. (May 27, 2018). Muksri, S . (2003). India was a role model of the Siamese Reform in the reign of King Rama V. Available at http://54408.activeboard.com/t2619429/5/

Nathi, N.S .(2010). From Radenlandaj at the Beginning of Ratankosin to People Living in Public in Bangkok. Available at https://www.gotoknow.org/posts/344455.

Pantip, (2015). Impression after Reading Sivaaraati. Available at https://pantip.com/topic/ 34053932.

Phnomthien. (2013). Chulatrikhun. Bangkok: Phraew Publishing House.

Phnomthien. (2002). Sivaaraatri Vol.1-VIII. Bangkok: At Baan Wannakam Group.

Pichayaratana. (2009). Meet Each Other under the Star. Available at https://www.bloggang.com/ mainblog.php?id=pichayaratana\&month=01-042009\&group=1\&gblog=1.

Pitak (penname). (2014). Beggar in this country now. Available at http://oknation.nationtv. tv/mblog/entry.php?id=914390.

Arab World English Journal for Translation \& Literary Studies

ISSN: 2550-1542 | www.awej-tls.org 
AWEJ for Translation \& Literary Studies Volume, 3 Number 2. May 2019

Inter-mixing Indiannesss with Thainesss in selected Thai Novels

Srichampa

Pramaha Montri. (2017). Radenlandaj. Available at https:/pantip.com/topic/340539325\%E0\% $\mathrm{B} 8 \% \mathrm{~B} 1 \% \mathrm{E} 0 \% \mathrm{~B} 8 \% 99 \% \mathrm{E} 0 \% \mathrm{~B} 9 \% 84 \% \mathrm{E} 0 \% \mathrm{~B} 8 \% 94$.

Soythong, P. and Tulaphitak, S. 1999. (He) is Phnomthien. Pantip. Available at https://pantip. com/topic/32685399.

Radenlandaj. (2018). Available at https://sites.google.com/site/thai059ssru/phu-Taeng.

Rama I. (n.d.). Available at https://en.wikipedia.org/wiki/Rama_I.

Rama III. (n.d.). Available at https://en.wikipedia.org/wiki/Rama_III.

Sahai, Sachchidananda. (2002). India in 1872 as Seen by the Siamese. New Delhi: B.R Publishing Corporation.

Satjaphan, Ruenruthai. (2013). Commemorative Certificate to Mrs. Ramphaiphan Suwannasarn

Srisophak. Available at http://www1.culture.go.th/thai/images/stories/ news/160157/03.pdf.

Sophak Suwan. (2008). Jusmina-Mahal Vol. I and II. Bangkok: Buraphasaan Co.,Ltd.

Sophak Suwan. (2013). Meet Each Other under the Star. phop-kan-taajduang-daaw). Bangkok:

Khlang Withaya Publishing House.

Sophak Suwan. (2018). Available at https:/th.wikipedia.org/wiki.

Sri-Udom, Kanthika.(2018). Discussion of King Rama V's book Visited India. Available at http://daily.khaosod.co.th/view_news.php?newsid.

Sophapong. A. (n.d.). Available at http://www.winbookclub.com/popup.php?type=2 \&interviewid=36.

Sumethi, Phanuwat. (2016). Meet the writers: From scripts to a Romantic novel of Chayaphim.

Available at http:/www.all-magazine.com/ColumnDetail/allColumDetail/tabid/106/articleType/ Article View/articleId/5430/.aspx.

Tam. (2018). Sentimental Poem Collections from a Chapter in the Novels. Available at https://writer.dek-d.com/writer/story/viewlongc.php?id=117900\&chapter=5.

Terwiel. Baren Jan.1983. A history of modern Thailand, 1767-1942. St. Lucia, Qld.: University of Queensland Press.

Thommayanti. (2017). Available at https://en.wikipedia.org/wiki/Thommayanti.

Thomyanti. 2008. Sivalaj. Vol. I, II. Bangkok: At Wannakam House Group.

Vitchayaprakorn, Karnchana. 2006. Humor Fabrication in the Parody Literature: Radenlandaay.

Journal of Humanities, Narasuan University Vol. 3/2 Available at http://Www.human. nu.ac.th/jhnu/journal_detail.php?m=4\&a=50.

Warangkhana. (1994). Sari. Bangkok: Double Nine Publishing House.

Wimon Chiamcharoen. (2017). Available at https:/th.wikipedia.org/wiki.

Wongthet, Sujit. (2016). King Rama V Visited Colonised Surrounding Countries of Siam for

Learning to Reform the Modernised Country. Available at

https://www.matichon.co.th/columnists/news_332057.

Arab World English Journal for Translation \& Literary Studies

ISSN: 2550-1542 | www.awej-tls.org 